Ivanenko Olena, PhD, Associate Professor, Department of Ecology and Technology of Plant Polymers, National Technical University of Ukraine «Igor Sikorsky Kyiv Polytechnic Institute», Ukraine, e-mail: olenka.vasaynovich@gmail.com, ORCID: http://orcid.org/ 0000-0001-6838-5400

Radovenchyk Vyacheslav, Doctor of Technical Scienses, Professor, Department of Ecology and Plant Polymers Technology, National
Technical University of Ukraine «Igor Sikorsky Kyiv Polytechnic Institute»,Ukraine, e-mail: dokeco@ukr.net,ORCID: http://orcid.org/ 0000-0001-5361-5808

Radovenchyk Iaroslav, PhD, Associate Professor, Department of Ecology and Plant Polymers Technology, National Technical University of Ukraine «Igor Sikorsky Kyiv Polytechnic Institute», Ukraine, e-mail:r.yar@ukr.net, ORCID:http://orcid.org/0000-0002-0101-0273

\section{Chasov D., Belmas I., Vernyhora V., Kolyada B.}

\title{
DETERMINATION OF EFFECTIVE ENERGY CAPACITY OF THE CONVEYOR WHEN TRANSPORTING DIFFERENT WASTE OF MECHANICAL TREATMENT
}

The object of research is the process of transportation of mechanical waste from the machine tool to the area of further processing using a modernized screw conveyor. One of the biggest problems in the transportation of mechanical waste remains the high cost of auxiliary processes, which form the final cost of the product. Since it is impossible to reduce the cost by excluding the stages of transportation and processing from the technological process, the energy component of the issue remains. Reducing energy costs at all stages of machining, transportation and processing is an important economic and environmental challenge.

In this work, the energy consumption of the conveyor is determined during the transportation of the shavings obtained during the end turning of the gear rim of the wheel. Also, the work is devoted to the movement of sludge obtained by surface grinding of the cover of a cylindrical gearbox. The examined shavings and sludge are in different states: dry, wet and unprepared.

The analysis of the existing effective equipment for cleaning and moving with the stages of cleaning and processing of cutting fluids, shavings and sludge, taking into account the energy intensity, is carried out. A comparative analysis of the energy consumption of the conveyor, taking into account the energy consumption for the preparation of the transported material - the drying process, is carried out. Recommendations are given regarding the cases of using a dryer for the preparation of shavings and sludge for the processes of moving to the processing, cleaning or disposal zones. The effective values of the energy consumption of the conveyor are determined on the basis of graphical dependencies, based on the conditions of a given productivity.

It is shown that obtaining the effective energy consumption of the conveyor is achieved due to the combined accounting of the energy consumption of the conveyor and equipment for the preparation of chips and sludge. This saves 5-7\% in energy costs for an expected performance of $12.4 \mathrm{~g} / \mathrm{min}$. As a research result, it is concluded that the effective energy consumption of the conveyor is 70-90 W/min for a given productivity of $10-12 \mathrm{~g} / \mathrm{min}$ when transporting wet sludge and shavings.

Keywords: cutting fluids, waste transportation, chip processing, sludge processing, disposal.

Received date: 19.05.2020

Accepted date: 26.06 .2020

Published date: 31.10 .2020
Copyright (C) 2020, Chasov D., Belmas I., Vernyhora V., Kolyada B. This is an open access article under the CC BY license (http://creativecommons.org/licenses/by/4.0)

\section{Introduction}

During machining, cutting fluids (coolants) and detergents are used. When machining parts by cutting, the coolant enters the cutting zone, must be clean and free from chips, sludge and other impurities that reduce the cooling and lubricating effect. Contamination in the coolant can lead to a number of other negative consequences. The transportation of machining wastes occurs both with and without coolant. Moving coolant, chips and sludge is a component of the production cost, to reduce which it is necessary to use variable technologies. These technologies include a decrease in electricity consumption due to the refinement of processing processes - switching off/on with the stages of transportation drying of chips and sludge, because the process of drying the chips and separating the cutting fluid from the sludge consumes up to $40 \%$ of the energy consumption of the processing process.

There is little research into efficient equipment for cleaning cutting fluids in terms of energy intensity. So, work [1] 
is devoted to centrifugal cleaning. But the quantitative energy consumption has not been fully investigated. The work [2] is devoted to the choice of the type of treatment and transportation methods for circulating methods of supplying liquids and there is no analysis of energy efficiency at all. Works [3, 4] are devoted to alternative methods of transportation and regeneration of liquids, taking into account the economic feasibility of the project. And yet the degree of economic efficiency on the part of energy consumption in comparison with similar methods remains uncertain. Works [5, 6] are devoted to improving the methods of transportation, processing and degreasing of wastewater. In these studies, the energy component of the issue remains unrevealed. The work [7] is devoted to the determination of the productivity and energy consumption of the conveyor, but there is no comparative analysis of the energy consumption for various types of materials. Works [8, 9] are devoted to the improvement of conveyor designs. But there is no energy or economic calculations of the feasibility of projects. Work [10] is devoted to the performance of auxiliary equipment without taking into account its energy consumption.

Work on the improvement and research of movements, processing and disposal is aimed at increasing productivity, and not at the rational use of energy resources.

As the transported material, let's use the shavings obtained by the end turning of the gear rim of the wheel; sludge obtained by surface grinding of the spur gear cover. Sludge and shavings are sampled in three states: dry (predrying in a dryer), wet (pre-passing through mechanical filters) and unprepared (without any preparation - from the drainage system of the machine). The alternate loading of various states of the materials under study was accompanied by fixing the consumed electricity using a meter installed between the electric motor and the power supply point from the network. The disadvantage of this research method is the equipment error and the possibility of uneven distribution of the load, which will affect the heterogeneity of the results and is not covered by the experimental error.

Thus, the object of research is the process of transportation of mechanical waste from the machine tool to the zone of further processing using a modernized screw conveyor (Fig. 1) [11].

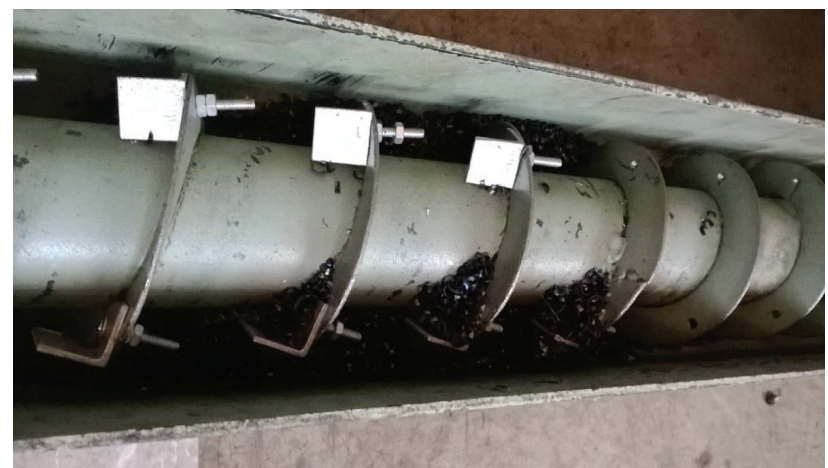

Fig. 1. Screw conveyor

The aim of research is to determine the effective energy consumption of the conveyor during the transportation of machining waste.

\section{Methods of research}

The study of the influence of various types of transported materials in various states on the level of electricity consumption was carried out in the intervals from 1.4 to $22.5 \mathrm{~g} / \mathrm{s}$ of the conveyor performance with a constant filling of the trough of $25-30 \%$.

To prepare dry shavings and sludge, an industrial dryer with a power of $5 \mathrm{~kW} / \mathrm{h}$ was used.

To obtain wet shavings and sludge, complex three-stage filters were used (the first stage retains particles larger than $0.1 \mathrm{~mm}$, the second stage - particles larger than $0.05 \mathrm{~mm}$, respectively, the third - more than $0.005 \mathrm{~mm}$ ).

\section{Research results and discussion}

Moving mechanical waste occurs in various ways, but the most common is the use of conveyor transport. The transportation stage can take place with unprepared materials (directly from the machine) or go through the stages of filtration, cleaning and drying.

Considering the cost of energy resources, they should be rationally used to reduce the cost of production. Since the transfer of waste is an integral part of the treatment process, it is important to reduce or efficiently use energy

Conducted research on the energy consumption of the conveyor during the transportation of various types of materials (Fig. 2, 3) shows the arithmetic dependence of the increase in consumption on the viscosity of the material and the specified performance. If performance is a positive factor, then it is not advisable to upgrade it.

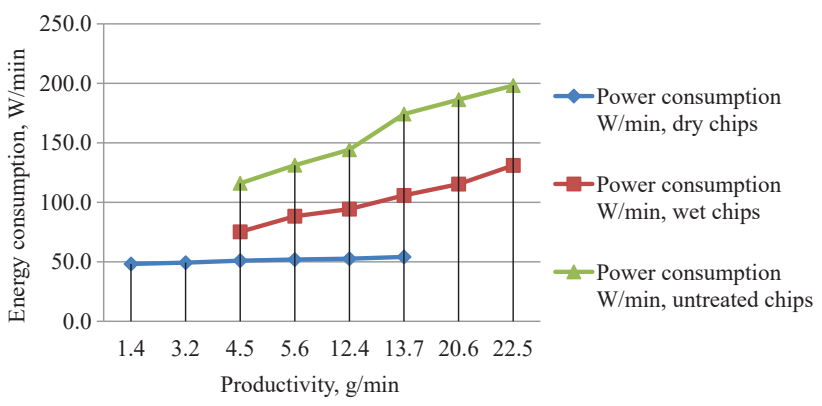

Fig. 2. Energy consumption of the conveyor when transporting chips

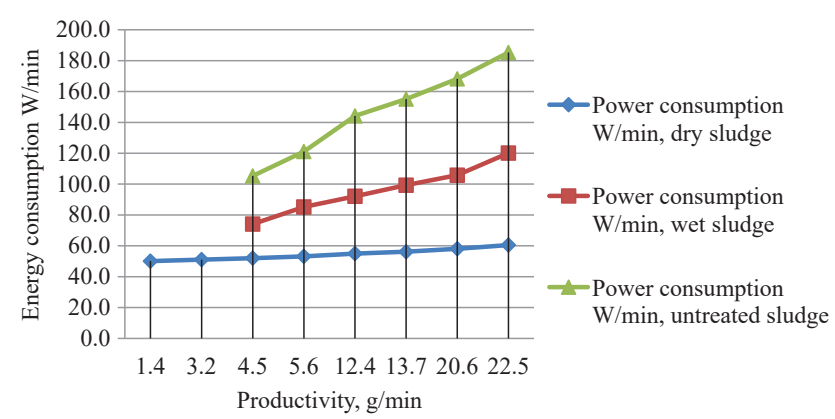

Fig. 3. Energy intensity of the conveyor when transporting sludge

As can be seen from the graphs in Fig. 2, 3, viscosity increases energy consumption. The viscosity of the waste can be understood as the difference in the state of the material from dry (prepared).

During the preliminary preparation, a filter system is used, which does not consume energy, but in many respects 
reduces its consumption by the conveyor when moving chips and sludge.

The use of a dryer for obtaining dry shavings and sludge helps to reduce the level of energy consumption, however, it is necessary to take into account the dryer's own energy consumption, which is $5 \mathrm{~kW} / \mathrm{h}$ (for a prototype, when converted to research values of $83 \mathrm{~W} / \mathrm{min}$ ).

As can be seen from the graphs in Fig. 2, 3, the use of the dryer is impractical in full, compared to the energy consumption of the conveyor when transporting wet sludge obtained by filtration without energy consumption. The feasibility of the dryer can be traced at the stage of transition to productivity of $12.4 \mathrm{~g} / \mathrm{min}$ and higher in comparison with unprepared material.

\section{Conclusions}

During the study, the energy consumption of the conveyor was determined when transporting shavings of various states:

- for dry chips ranging from 49 to $52 \mathrm{~W} / \mathrm{min}$;

- for wet shavings in the range from 75 to $131 \mathrm{~W} / \mathrm{min}$;

- for untreated chips from 75 to $200 \mathrm{~W} / \mathrm{min}$.

The energy consumption of the conveyor was also determined when transporting sludge of various states:

- for dry sludge in the range from 50 to $61 \mathrm{~W} / \mathrm{min}$;

- for wet sludge in the range from 74 to $120 \mathrm{~W} / \mathrm{min}$;

- for untreated sludge in the range from 105 to $185 \mathrm{~W} / \mathrm{min}$.

A comparative analysis of energy consumption is carried out, during which it is determined the feasibility of using filtering units and the use of dryers at a given productivity above $12.4 \mathrm{~g} / \mathrm{min}$.

Analyzing the above, it is possible to conclude that the effective energy consumption of the conveyor is $70-90 \mathrm{~W} / \mathrm{min}$ for a given productivity of $10-12 \mathrm{~g} / \mathrm{min}$ when transporting wet sludge and shavings.

\section{References}

1. Evstratova, A. V. (2007). Vliianie formy vnutrenneipoverkhnosti korpusa shnekovogo pressa na ego proizvoditelnost. Perspektivy razvitiia Vostochnogo Donbassa. Novocherkassk: UPTS «Nabla» IURGTU (NPI), 113-118.

2. Chasov, D. (2016). Determining the equation of surface of additional blade of a screw conveyor. Eastern-European Journal of Enterprise Technologies, 5 (1 (83)), 10-14. doi: http://doi.org/ 10.15587/1729-4061.2016.80606

3. De Abreu Domingos, R., da Fonseca, F. V. (2018). Evaluation of adsorbent and ion exchange resins for removal of organic matter from petroleum refinery wastewaters aiming to increase water reuse. Journal of Environmental Management, 214, 362-369. doi: http://doi.org/10.1016/j.jenvman.2018.03.022
4. Mannu, A., Vlahopoulou, G., Sireus, V., Petretto, G. L., Mulas, G., Garroni, S. (2018). Bentonite as a Refining Agent in Waste Cooking Oils Recycling: Flash Point, Density and Color Evaluation. Natural Product Communications, 13 (5), 613-616. doi: http://doi.org/10.1177/1934578x1801300523

5. Zheng, R., Gao, H., Ren, Z., Cen, D., Chen, Z. (2017). Preparation of activated bentonite and its adsorption behavior on oil-soluble green pigment. Physicochemical Problems of Mineral Processing, 53 (2), 829-845. doi: http://doi.org/10.5277/ ppmp170213

6. Gobbi, L. C. A., Nascimento, I. L., Muniz, E. P., Rocha, S. M. S., Porto, P. S. S. (2018). Electrocoagulation with polarity switch for fast oil removal from oil in water emulsions. Journal of Environmental Management, 213, 119-125. doi: http://doi.org/ 10.1016/j.jenvman.2018.01.069

7. Mirshafiee, A., Rezaee, A., Mamoory, R. S. (2018). A clean production process for edible oil removal from wastewater using an electroflotation with horizontal arrangement of mesh electrodes. Journal of Cleaner Production, 198, 71-79. doi: http:// doi.org/10.1016/j.jclepro.2018.06.201

8. Abdulsalam, M., Che Man, H., Isma Idris, A., Faezah Yunos, K. Zainal Abidin, Z. (2018). Treatment of Palm Oil Mill Effluent Using Membrane Bioreactor: Novel Processes and Their Major Drawbacks. Water, 10 (9), 1165. doi: http://doi.org/10.3390/ w10091165

9. Meretukov, Z. A., Koshevoi, E. P., Kosachev, V. S., Vereschagin, A. G., Sled, N. I. (2011). Proizvoditelnost transportera so spiralnym shnekom. Novye tekhnologii, 1, 72-76.

10. Pezo, L., Jovanović, A., Pezo, M., Čolović, R., Lončar, B. (2015) Modified screw conveyor-mixers - Discrete element modeling approach. Advanced Powder Technology, 26 (5), 1391-1399. doi: http://doi.org/10.1016/j.apt.2015.07.016

11. Rud, A., Oligov, Y. (2011). Rational method of selecting the angle of the auger blade screw conveyor. News of higher educational institutions: the North-Caucasian region: engineering science, $5,55-57$.

Chasov Dmytro, PhD, Associate Professor, Department of Mechanical Engineering Technology, Dniprozsk State Technical University, Kamianske, Ukraine, e-mail: 0969995009@ukr.net, ORCID: http:// orcid.org/0000-0003-3830-693X

Belmas Ivan, Doctor of Technical Sciences, Professor, Department of Mechanical Engineering Technology, Dniprovsk State Technical University, Kamianske, Ukraine, e-mail: belmas09@meta.ua, ORCID: http:// orcid.org/0000-0003-2112-0303

Vernyhora Viktor, PhD, Associate Professor, Department of Occupational Safety and Health, Dniprovsk State Technical University, Kamianske,Ukraine, e-mail:vernyhora.viktor@gmail.com,ORCID: http:// orcid.org/0000-0002-2536-4420

Kolyada Bogdan, Postgraduate Student, Department of Mechanical Engineering Technology, Dniprovsk State Technical University, Kamianske,Ukraine, e-mail: bog456@ukr.net, ORCID: http://orcid.org/ 0000-0001-8865-8277 